\title{
Kualitas dan Cara Penyimpanan Telur Yang Baik dalam Upaya Menjaga Asupan Gizi Optimal di Masa Pandemi COVID-19
}

\section{The Quality and Good Method of Storing Eggs in an Effort to Maintain Optimal Nutrition during the COVID-19 Pandemic Period}

\author{
Ken Ratu Gharizah Alhuur ${ }^{1}$, Andry Pratama ${ }^{2}$, Endah Yuniarti ${ }^{3}$
}

* Korespondensi Penulis:

\section{Ken Ratu Gharizah Alhuur}

E-mail: Kenalhuur@gmail.com

${ }^{1}$ Fakultas Peternakan, Universitas

Padjadjaran

${ }^{2}$ Departemen Pengolahan Hasil

Ternak, Fakultas Peternakan,

Universitas Padjadjaran

${ }^{3}$ Program Studi Peternakan

k.Pangandaran, Universitas

Padjadjaran

Submitted July 28, 2020.

Revised Aug 4, 2020.

Accepted Aug 25, 2020.

\section{Abstract}

Optimal nutritional intake, especially protein intake, both during the Covid-19 pandemic and in normal situations, is important to fulfill. Eggs are a source of protein with prices that are quite affordable compared to other animal protein sources, such as meat and milk. So people prefer eggs as a fulfillment of their daily protein needs compared to meat and milk. During the Covid-19 pandemic, many impromptu egg sellers emerged in the community, as one of the effects of the drop in egg prices on the market. However, these impromptu egg sellers often disregard the quality of the eggs they sell. This will certainly have detrimental and harmful consequences to consumer health. For this reason, socialization to the public about how to differentiate egg quality and how to storing eggs in a good way is important, so that people can choose and get good quality eggs in a longer period of time. The benefit of this socialization is that participants become more careful in choosing the eggs they buy and knowing how to store eggs properly so that the shelf life of the eggs they buy can last longer.

Keywords: nutritional intake, eggs quality, eggs storage

\section{Abstrak}

Asupan gizi yang optimal terutama asupan protein, baik dimasa pandemi Covid-19 maupun dalam situasi normal, penting untuk dipenuhi. Telur merupakan salah satu pangan sumber protein dengan harga yang cukup terjangkau dibandingkan sumber protein hewani lain, seperti daging dan susu. Sehingga telur banyak dipilih oleh masyarakat luas dalam pemenuhan kebutuhan protein harian mereka. Dalam masa pandemi Covid-19 ini, banyak bermunculan pedagang telur dadakan di kalangan masyarakat, sebagai salah satu imbas dari anjloknya harga telur di pasaran. Namun, para pedagang telur dadakan ini seringkali tidak mengindahkan kualitas telur yang mereka jual. Hal ini tentu akan berakibat merugikan dan membahayakan bagi kesehatan konsumen. Untuk itu, sosialisasi kepada masyarakat mengenai cara membedakan kualitas telur dan cara penyimpanan telur yang baik menjadi penting untuk dilakukan, agar masyarakat dapat memilih dan mendapatkan telur dengan kualitas yang baik dalam jangka waktu yang lebih Panjang. Manfaat dari sosialisasi ini adalah partisipan menjadi lebih teliti dalam memilih telur yang mereka beli, dan mengetahui cara penyimpanan telur yang benar agar masa simpan telur yang mereka beli dapat bertahan lebih lama.

Kata Kunci: asupan gizi, kualitas telur, cara penyimpanan telur

\section{Pendahuluan}

Kesadaran masyarakat mengenai pentingnya pemenuhan gizi harian semakin meningkat terutama pada masa pandemi Covid-19 seperti saat ini, dimana masyarakat semakin peduli dengan kualitas makanan yang dikonsumsinya agar kondisi daya tahan tubuhnya tetap optimal. Hal ini berpengaruh terhadap jumlah permintaan terhadap produk-produk 
pangan sumber protein hewani, salah satunya adalah telur ayam. Berdasarkan data dari Direktorat Jendral Peternakan dan Kesehatan Hewan Kementan (2018), konsumsi telur ayam dari tahun 2017-2018 mengalami kenaikan sebanyak $6,6 \%$ dan setiap tahunnya terus mengalami peningkatan. Telur ayam banyak dipilih oleh masyarakat luas selain karena manfaat dari kandungan gizi kompleks di dalamnya, juga karena harganya yang jauh lebih murah dibandingkan produk pangan sumber protein hewani lainnya, seperti yang disampaikan dalam data Survey Sosial Ekonomi Nasional dalam BPS (2019) bahwa angka konsumsi telur lebih tinggi dibandingkan dengan angka konsumsi komoditas pangan sumber protein hewani lainnya. Terutama pada masa awal pandemi Covid-19, dimana harga telur di pasaran sempat anjlok dan menjamurnya pedagangpedagang telur dadakan di masyarakat. Sayangnya, para pedagang telur dadakan ini seringkali tidak dibekali dengan pengetahuan mengenai cara penyimpanan telur yang baik, sehingga kualitas telur yang beredar di masyarakat tidak terjamin.

Telur yang dikonsumsi semestinya memenuhi kriteria layak konsumsi yang dapat dinilai berdasarkan kualitas fisik atau penampakannya, mikrobiologis, dan tentunya diterima secara organoleptik. Proses pendistribusian telur dari produsen sampai ke tangan konsumen umumnya melalui alur yang cukup panjang, sehingga usia telur saat sampai ke tangan konsumen sudah dalam usia telur beberapa hari atau tergolong tidak baru lagi. Umur telur yang sampai ke tangan konsumen umumnya sudah berkisar lebih dari 7 hari (Suharyanto, 2007). Kandungan gizi kompleks terutama protein yang tinggi di dalam telur menyebabkan telur menjadi tempat berkembangbiak yang baik bagi mikroorganisme, termasuk mikroorganisme pathogen seperti coliform, Eshericia coli, dan Salmonella sp yang dapat menyebabkan penyakit apabila penanganan atau penyimpanannya tidak diperhatikan dengan baik, terlebih apabila telur sudah berumur lebih dari 1 minggu.

Pengetahuan untuk membedakan kualitas telur yang akan dibeli dan cara penyimpanan telur yang baik menjadi penting untuk diketahui, agar telur yang kita konsumsi selalu terjamin kualitasnya. Sehingga tujuan dari mengonsumsi telur, yaitu untuk menjaga daya tahan tubuh agar tetap optimal terutama dimasa pandemi menjadi dapat tercapai. Informasi ataupun pengetahuan ini perlu disebarluaskan kepada hal layak sebagai konsumen telur, dan dalam kondisi pandemi sekarang ini penyebarluasan informasi dengan metode penyuluhan ataupun seminar banyak dilakukan melalui media daring, sehingga responden yang mengakses dan mendapatkan informasi bisa lebih luas dan beragam.

\section{Materi dan Metode Pelaksanaan}

Kegiatan sosialisasi mengenai "Kualitas dan Cara Penyimpanan Telur yang Baik dimasa Pandemi Covid-19" ini dilakukan secara daring, dalam rangkaian webinar series Fakultas Peternakan Universitas Padjadjaran, pada masa Work From Home (WFH) selama masa pandemic Covid-19. Sosialisasi ataupun webinar ini menggunakan aplikasi Zoom meet, sehingga memungkinkan banyak kalangan dari berbagai instansi maupun umum untuk dapat bergabung dalam kegiatan sosialisasi materi dan turut dalam diskusi. Tahapan yang dilakukan dalam pelaksanaan sosialisasi ini sebagai berikut:

1. Persiapan

a. Observasi masalah, studi literatur, serta penyiapan narasumber yang mendukung untuk memecahkan persoalan yang terjadi

b. Perijinan dan penentuan target partisipan yang mengikuti sosialisasi

2. Adapun rangkaian kegiatan webinar ini sebagai berikut:

a. Pembukaan, dibuka dan dipandu oleh moderator

b. Sesi pemaparan materi mengenai kualitas telur dan cara penyimpanan telur yang baik

c. Sesi tanya jawab dan diskusi

Evaluasi partisipan mengenai materi yang didapatkan dengan menjawab questioner yang disebarkan melalui google form.

\section{Hasil dan Pembahasan}

Kegiatan sosialisasi dan diskusi mengenai "Kualitas dan cara penyimpanan telur yang baik dimasa pandemi Covid-19" ini diikuti sebanyak 83 Orang, yang terdiri dari kalangan akademisi, praktisi, maupun umum. Diharapkan dengan beragamnya latar belakang partisipan yang mengikuti webinar ini, informasi yang diberikan dapat tersebar secara optimal dan dapat memberikan manfaat secara luas. Berdasarkan pertanyaan - 
pertanyaan partisipan saat mengikuti webinar diketahui bahwa pengetahuan partisipan sudah cukup baik mengenai kualitas telur. Namun mengenai cara memeriksa atau mengetahui kualitas telur yang baik serta cara penyimpanan telur yang baik perlu ditingkatkan. Post-test dilakukan setelah webinar dilaksanakan, dan didapatkan hasil pengetahuan partisipan yang lebih baik mengenai cara pemeriksaan kualitas telur dan cara penyimpanan telur yang baik, seperti ditampilkan pada tabel 1.

Tabel 1. Pemahaman partisipan mengenai kualitas dan cara penyimpanan telur.

\begin{tabular}{lcc}
\hline \multicolumn{1}{c}{ Uraian Pertanyaan } & Ya & Tidak \\
\hline $\begin{array}{l}\text { Mampu membedakan kualitas } \\
\text { telur secara eksterior maupun }\end{array}$ & $82 \%$ & $12 \%$ \\
interior \\
$\begin{array}{l}\text { Mampu membedakan kualitas } \\
\text { telur melalui pengamatan atau } \\
\text { perlakuan sederhana }\end{array}$ & $96 \%$ & $4 \%$ \\
$\begin{array}{l}\text { Mampu melakukan } \\
\text { penyimpanan ataupun } \\
\text { pengawetan telur yang benar } \\
\text { Mampu membedakan antara } \\
\text { telur konsumsi dengan telur }\end{array}$ & $87 \%$ & $3 \%$ \\
HE & & \\
\hline
\end{tabular}

Kandungan nutrisi yang terkandung dalam telur sangat lengkap, dimana secara alami mengandung vitamin D, A, B2, B6, B12, asam folat, dan mineral yang sangat baik seperti zat besi, kalsium, natrium, dan fosfor. Dalam seminar online ini dijelaskan mengenai kandungan nutrisi lengkap pada telur ini menjadikan telur sangat baik untuk dijadikan sebagai sumber energi, sebagai pemenuh kebutuhan nutrisi sepanjang tingkatan usia dan juga baik untuk memelihara kesehatan jantung, sehingga anggapan publik mengenai konsumsi telur berbahaya bagi kesehatan jantung dapat diluruskan, karena berdasarkan penelitian yang dilakukan oleh Fuller, et al. (2015) membuktikan bahwa konsumsi telur tidak beresiko terhadap terjadinya penyakit kardiometabolis baik pada orang yang tidak memiliki masalah kesehatan, memiliki penyakit kardiovaskular maupun memiliki penyakit diabetes melitus Tipe 2, bahkan dapat dijadikan sebagai bagian dari menu diet sehat harian.

Penilaian kualitas telur melalui penampakan secara ekterior dan interior disampaikan dalam seminar online ini. Secara eksterior telur yang baik harus dalam keadaan ovoid, tidak retak, dan bersih, sementara secara interior tidak terdapat bercak darah ataupun benda asing, putih telur kental, kuning telur yang masih kompak, dan bau khas telur, seperti syarat mutu telur sesuai SNI 3926-2008 yang ditampilkan pada tabel 2. Menurut Kasmiati (2018), penilaian mutu telur meliputi kebersihan, bentuk telur, warna kuning telur, rongga udara, haugh unit, dan indeks albumen.

Jenis-jenis bakteri pathogen yang terkandung dalam telur juga dibahas dalam seminar online ini, beberapa jenis bakteri pathogen tersebut diantaranya adalah bakteri enterobakter, E. coli, Proteus, dan Salmonella yang umumnya berasal dari saluran reproduksi induk ayam, seperti yang disampaikan oleh Al-Bahry et al. (2012). Namun untuk penghitungan jumlah bakteri telur kurang praktis untuk dilakukan oleh konsumen saat hendak membeli telur, sehingga untuk penghitungan jumlah dan jenis bakteri tidak dibahas mendalam dalam seminar online ini. Pembahasan mengenai bakteribakteri pathogen yang dapat terkandung dalam telur hanya dijelaskan secara singkat saja sebagai pengantar untuk meningkatkan awareness masyarakat terhadap kualitas telur yang mereka beli.

Penilaian kualitas atau mutu telur dapat dilakukan dengan cara memasukkan telur ke dalam wadah berisi air. Apabila telur tidak mengapung, dan tetap tenggelam di dalam dasar wadah, maka kualitas telur masih sangat baik, dan berusia dikisaran di bawah satu minggu. Semakin telur tidak dapat mempertahankan posisinya di dasar wadah, hal tersebut menunjukkan bahwa telur sudah lebih tua, karena rongga udara di dalam telur semakin besar. Ilustrasi mengenai penilaian kualitas telur dengan cara memasukkan telur ke dalam wadah berisi air ditampilkan dalam Gambar 1.

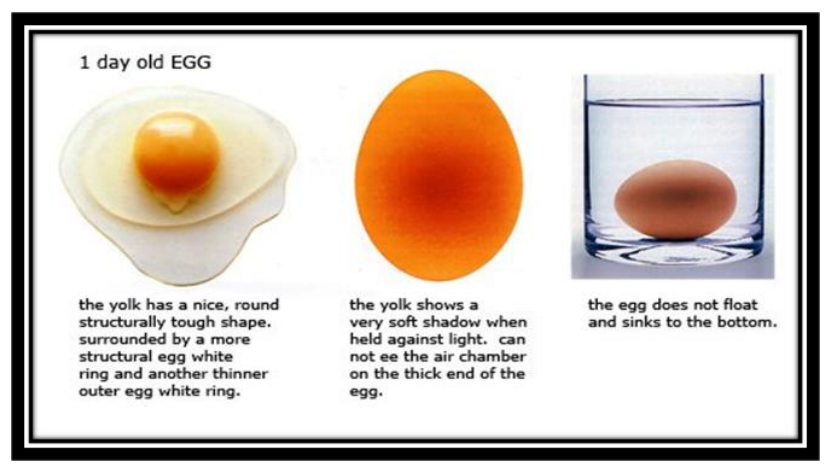



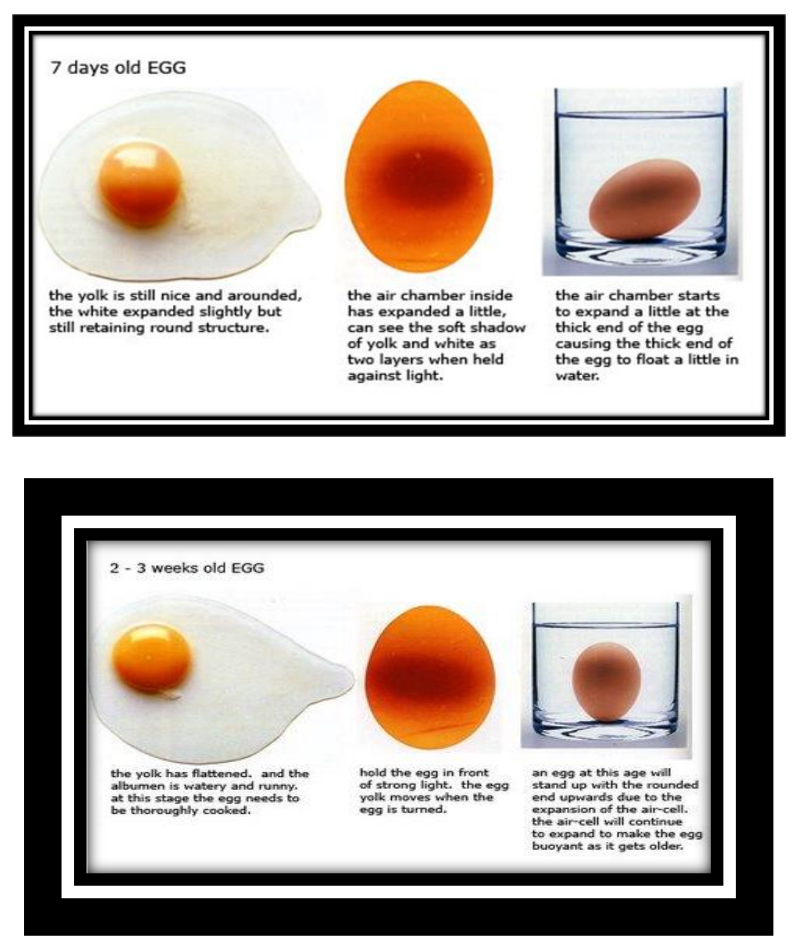

Gambar 1. Penilaian kualitas telur melalui media air

Namun penilaian kualitas telur dengan cara memasukkan telur ke dalam wadah berisi air ini dinilai kurang efektif, karena memerlukan media wadah dan air untuk pengecekannya. Sementara pada kenyataannya hal tersebut sulit dilakukan pada saat proses jual beli telur. Pada sesi diskusi seminar online ini didapatkan cara untuk pengecekan kualitas telur yang lebih praktis, yaitu melalui metode penyinaran menggunakan senter yang terdapat pada ponsel. Dengan metode ini, rongga udara dan posisi kuning telur di dalam kulit telur dapat terlihat, sehingga kualitas atau telur yang dibeli dapat dinilai dengan mudah.

Penanganan telur bermanfaat untuk mempertahankan kualitas telur, sehingga telur dapat dikonsumsi dalam waktu yang lebih panjang. Penanganan telur yang biasa dilakukan diantaranya adalah dengan metode pembersihan telur segera setelah telur dikoleksi, pengemasan kering untuk memperlambat hilangnya air dan $\mathrm{CO}_{2}$, perendaman telur (Sulistina et al., 2013), pencelupan telur ke dalam berbagai jenis larutan (wulandari, et al. 2013 dan Tindjabate, et al., 2014), penutupan pori-pori telur dengan penyamak nabati (Riawan, et al. 2017), dan yang paling mudah dan praktis untuk dilakukan oleh masyarakat umum yaitu penyimpanan dingin.
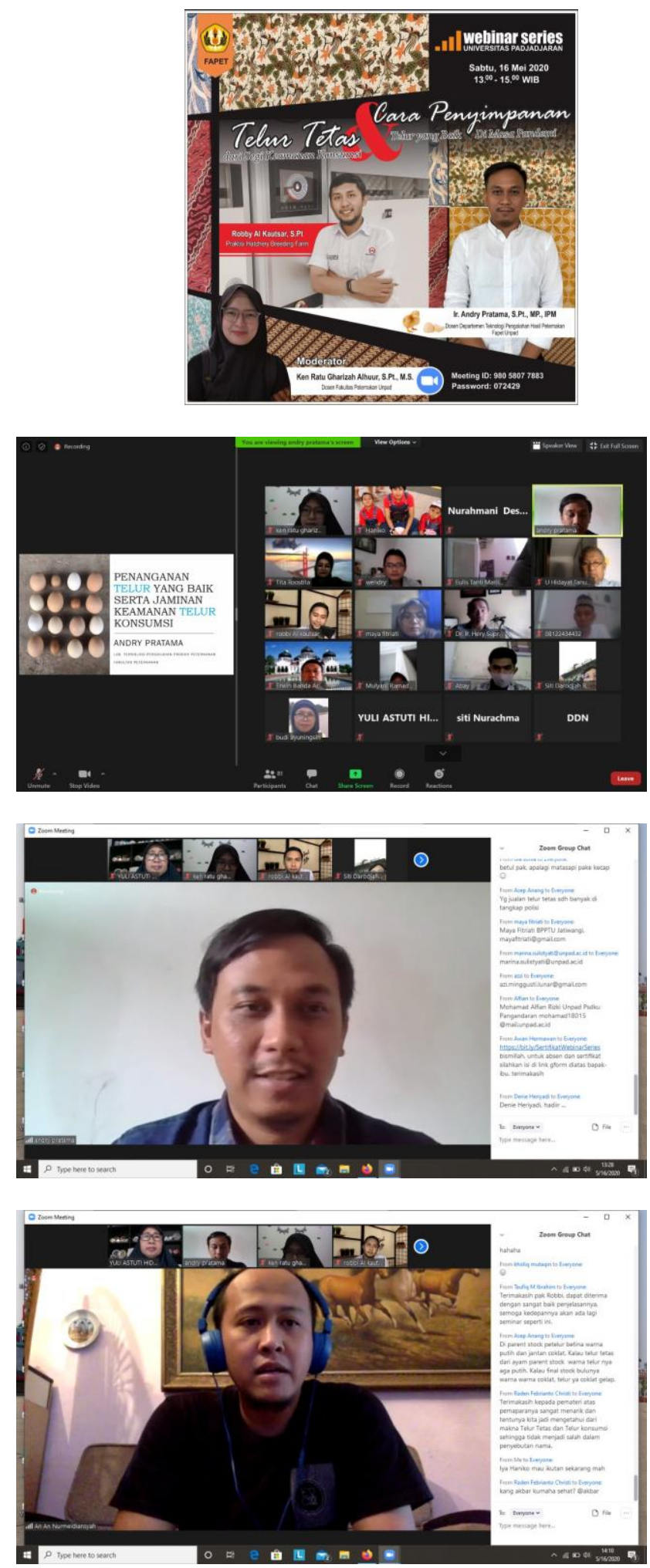

Gambar 2. Proses penyampaian materi dan diskusi pada seminar online "Kualitas dan Cara

Penyimpanan Telur yang Baik dimasa Pandemi Covid-19"

Kesimpulan

Pengetahuan partisipan mengenai pentingnya mengetahui kualitas telur yang mereka 
beli sudah baik, hal ini sejalan dengan kesadaran mereka akan pentingnya pemenuhan gizi dan kualitas gizi pangan yang mereka konsumsi. Namun sebagian besar partisipan belum mengetahui cara praktis untuk mengetahui kualitas telur dan cara untuk memperpanjang masa simpan telur yang mereka beli. Setelah pemaparan materi dalam seminar ini dilakukan, partisipan menjadi tau cara mudah untuk mengetahui kualitas telur yang akan mereka beli dan apa yang akan mereka lakukan saat penyimpanannya. Diharapkan ke depannya setiap produk telur yang dijual ke masyarakat telah dilengkapi dengan tanggal telur dihasilkan, agar kualitasnya dapat lebih mudah untuk dinilai.

\section{Daftar Pustaka}

[BPS] Badan Pusat Statistik. 2019. Konsumsi Kalori dan Protein Penduduk Indonesia dan Provinsi. Survey Sosial Ekonomi Nasional (Susenas). Badan Pusat Statistik.

[BSN] Badan Standarisasi Nasional. 2008. Telur Ayam Konsumsi (SNI 3926:2008). Jakarta. Badan Standarisasi Nasional.

Direktorat Jenderal Peternakan dan Kesehatan Hewan, Kementan. 2018. Statistik Peternakan dan Kesehatan Hewan. Direktorat Jenderal Peternakan dan Kesehatan Hewan. Kementerian Pertanian RI.

Al-Bahry S., I. Mahmoud S., Al-Musharafi M., Al-Ali. 2012. Penetration of Spoilage and Food Poisoning Bacteria Into Fresh Chicken Egg: a Public Health Concern. Global Journal of Bio-Science and Biotechnology. 1(1):33-39.

Fuller N. R., Sainsbury A., Caterson Ian D., Markovic Tania P. 2015. Egg Consumption and Human Cardio-Metabolic Health in People With and Without Diabetes. Nutrients. 7:7399-7420; doi:10.3390/nu7095344.

Kasmiati, Lumatauw S., Sumpe I. 2018. Uji Kualitas Telur Ayam Ras di Kota Manokwari. Jurnal Ilmu Peternakan. 8(1): 9-18.

Riawan, Riyanti, Nova Khaira. 2017. Pengaruh Perendaman Telur Menggunakan Larutan Daun Kelor Terhadap Kualitas Internal Telur Ayam Ras. Jurnal Ilmiah Peternakan Terpadu. 5(1): 1-7.

Suharyanto. 2007. Umur dan berat telur ayam ras yang beredar di Kota Bengkulu. Jurnal Sain Peternakan Indonesia. 2(1):22-26.
Sulistina Lilis, Imanudin Oki, Falahudin Aaf. 2017. Pengaruh Perendaman Ekstrak Teh Hijau (Camellia sinensis) Terhadap Kualitas Interior Kulit Ayam Ras. Jurnal Ilmu Pertanian dan Peternakan. 5(2): 198-203.

Tindjabate R. Stenly, Suada I Ketut, Rudyanto Mas Djoko. 2014. Pengawetan Telur Ayam Ras dengan Pencelupan dalam Ekstrak Air Kulit Manggis pada Suhu Ruang. Indonesia Medicus Veterinus. 3(4):310-316.

Wulandari Eka, Rachmawan Obin, Tafik Ahmad, Suwarno Nono, Faisal Ahmad. 2013. Pengaruh Ekstrak Daun Sirih (Pipper Betle.L) sebagai Perendam Telur Ayam Ras Konsumsi Terhadap Daya Awet pada Penyimpanan Suhu Ruang. ISTEK. 7(2): 163-174. 